\title{
Chapter 9 \\ Addressing Food Insecurity in Papua New \\ Guinea Through Food Safety and Sago Cropping
}

\author{
Aisak G. Pue, Mary T. Fletcher, Barry Blaney, Andrew R. Greenhill, \\ Jeffery M. Warner, Atagazli Latifa, and Jack C. Ng
}

\begin{abstract}
Papua New Guinea (PNG) is known to have a large resource base of sago with over 1 million ha, as well as a high number of germplasm types of the Metroxylon species. The country's food security status is very low and is primarily dependent on subsistence fresh garden produce as practiced by $85 \%$ of the population who are rural dwellers. Postharvest losses can be as high as $40 \%$ with little to no postharvest technology nor processing of foods done. Sago provides well for food security and sustains life in rural communities during disasters such as droughts, floods, and cyclones. The dilemma of sago being an underutilized crop in PNG is exacerbated by the introduction of new food crops, cash crops, and limited accessibility to cash to purchase other foods. Over the last 50 years, sago consump-
\end{abstract}

The original version of this chapter was revised.

An erratum to this chapter can be found at https://doi.org/10.1007/978-981-10-5269-9_25

A.G. Pue $(\square)$

Papua New Guinea University of Natural Resources and Environment,

PMB Kokopo, Papua New Guinea

e-mail: apue@unre.ac.pg; aipue@ hotmail.com

M.T. Fletcher • B. Blaney

Queensland Alliance for Agriculture and Food Innovation, University of Queensland,

Coopers Plains, QLD, Australia

e-mail: mfletcher@uq.edu.au; bblaney@dpi.qld.gov.au

A.R. Greenhill

Monash University, Melbourne, VIC, Australia

e-mail: andrew.greenhill@federation.edu.au

J.M. Warner • A. Latifa

Department of Microbiology and Immunology, School Vet and Biomed Science, James Cook

University, Townsville, QLD, Australia

e-mail: jwarner@jcu.edu.au

J.C. Ng

National Research Centre for Environmental Toxicology, University of Queensland,

Coopers Plains, QLD, Australia

e-mail: jng@uq.edu.au

H. Ehara et al. (eds.), Sago Palm, https://doi.org/10.1007/978-981-10-5269-9_9 
tion has diminished as one of the major traditional food staples, from $16 \%$ to less than $10 \%$. Neglect of sago is further due to food safety concerns about traditionally processed sago, in particular, the risk from sago hemolytic disease (SHD). For over 30 years, SHD has been a food safety issue since it was first reported in 1973. Investigations on SHD highlight the serious need to improve on the hygiene and sanitation of the traditional postharvest processing and storage methods of sago starch in PNG. A set of hazard analysis and critical control point (HACCP) protocols has been developed for traditional processing of sago as a food safety measure to improve food safety for food security. While commercial cultivation is nonexistent, there is increased planting of the larger hapaxanthic, non-soboliferous sago species, Metroxylon salomonense Becc., in some nontraditional sago-consuming areas as a low-cost raw material source for roof thatching and other building materials. It is however a wasted opportunity for food security in these areas as the starch from the palm is not utilized. Current work in these areas promotes sago as a potential food source that can be harvested or processed into flour. This is to improve the food security status in areas of high population density, like island communities where land is scarce.

\subsection{Background}

The island of New Guinea, shared between Papua New Guinea (PNG) and Indonesia, has the largest combined sago resources, with well over 2 million ha or $88 \%$ of global sago stocks (Schuiling 1995). The island is also regarded as the center of sago diversity. Genetic studies by Kjari et al. (2004) reveal that only one species of Metroxylon sagu exists but with many cultivars (Boonsermsuk et al. 1999; Kjari et al. 2004).

The inhabitants of New Guinea island, as in other sago-producing countries of the Western Pacific and Southeast Asia (McClatchey et al. 2004, 2006), rely chiefly on sago for their livelihood needs. Sago leaves are used for roof thatching, the leaf midribs are bundled into a broom, and the bark of the trunk is used as a building material for floors, walls, or fences. The seeds of the flowering palm are used as ornaments or other decorations, while the roots are used as a source of medicine (Flach 1980; Gemo 1999).

Unlike other foods, sago has a very high food security level both as a live commodity and as processed starch that can be conveniently used. Sago starch has many uses as food and as material feedstock for industrial applications (Abd-Aziz 2002). In PNG sago starch is mostly eaten in the rural coastal regions where it is cultivated or exists in the wild. Sago is also indigenous to several inland lowland communities of the highlands region of PNG. In the Karimui District of the Simbu Province, the Purari River, and Fly River tributaries, such as lakes Murray, Kutubu, and Kopiago in the Southern Highlands Province, sago is a staple food (Sopade 1999). Food security of sago in PNG is, however, hampered by food safety issues, in particular the incidence of the rare sago hemolytic disease (SHD) reported in three provinces in the past, as shown by blue stars in the map (Fig. 9.1). 


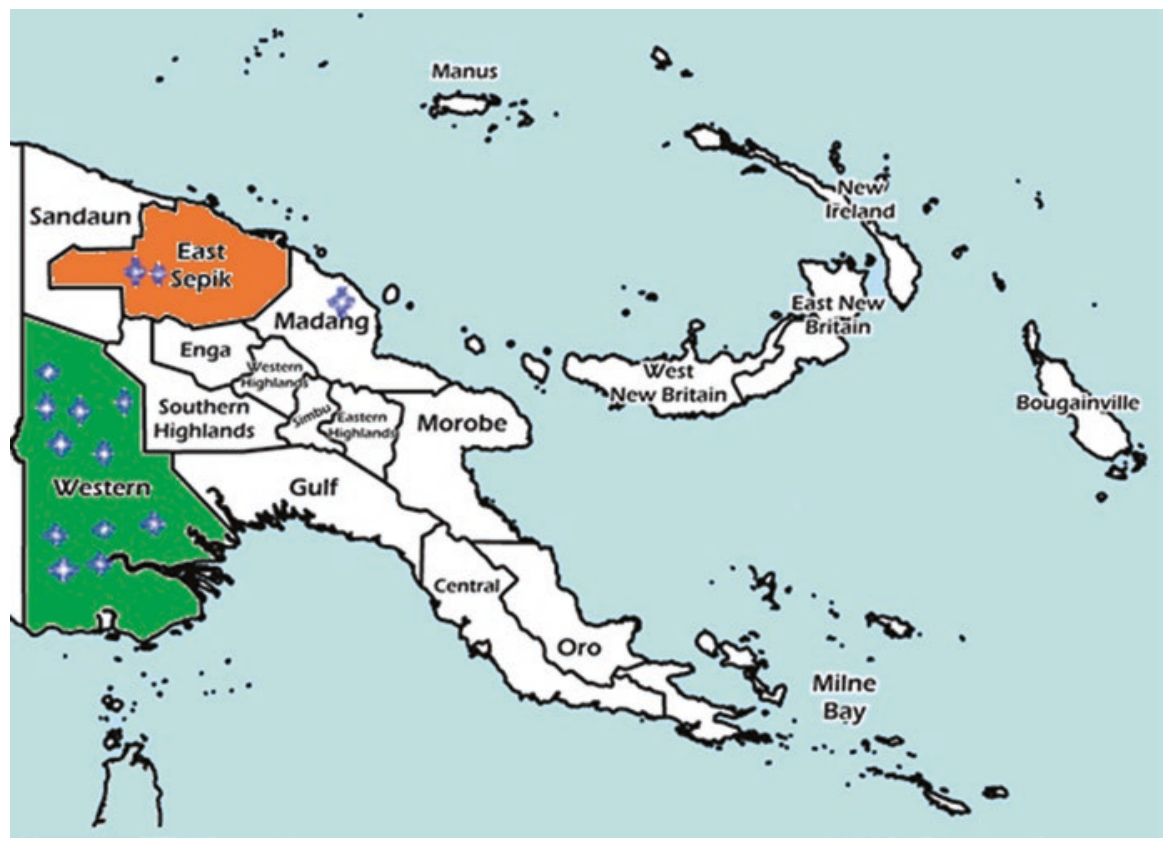

Fig. 9.1 Map of Papua New Guinea provinces, with East Sepik (orange) and Western Province (green) highlighted. Blue stars represent sago hemolytic disease outbreaks over the past 30 years. There were 2 in East Sepik, 1 in Madang, and 12 in the Western Province

\subsection{Significance of Sago to Papua New Guinea}

The PNG government recognizes sago as a major staple (Table 9.1), for almost 30\% of its seven million people (Bourke 2001). Sago making is the mainstay of low and wetland communities of PNG and plays a significant cultural role as a commodity of trade or being used in barter exchanges for other foods or goods, as in bride price ceremonies and for many other special occasions (Temu and Saweri 2001).

Virtually all sago starch in PNG is produced on a subsistence level in the villages with only the surplus being sold. The need for cash and encouragement by the authorities for economic development has caused villagers to produce more sago for marketing. Better transportation in the form of motorized canoes has greatly facilitated marketing of sago and improved the welfare of sago-producing communities, some of which are the poorest in PNG (Morauta 1982; Temu 2006).

There is no record of sago being exported from PNG into markets such as the 60 million mt market of Southeast Asia (Wang et al. 1996). There are small exports to the PNG communities overseas (e.g., Australia and New Zealand), but this is negligible compared to the total annual production.

Many rural communities are food insecure and rely solely on sago during periods of disasters like cyclones, floods, or droughts. The starch can be eaten for extended 
Table 9.1 Consumption patterns of Sago in Papua New Guinea

\begin{tabular}{|c|c|c|c|c|c|}
\hline \multirow[b]{3}{*}{ Province } & $\begin{array}{l}\text { Sago as a } \\
\text { dominant } \\
\text { staple }\end{array}$ & $\begin{array}{l}\text { Sago as a } \\
\text { subdominant } \\
\text { staple }\end{array}$ & \multirow[b]{3}{*}{$\begin{array}{l}\text { Total } \\
\text { population }\end{array}$} & \multirow{3}{*}{$\begin{array}{l}\text { Population } \\
\text { depending on } \\
\text { sago as a } \\
\text { dominant } \\
\text { staple }(\%)\end{array}$} & \multirow{3}{*}{$\begin{array}{l}\text { Population } \\
\text { depending on } \\
\text { sago as dominan } \\
\text { or subdominant } \\
\text { staple }(\%)\end{array}$} \\
\hline & $\begin{array}{l}\text { Population } \\
\text { depending on } \\
\text { sago as a } \\
\text { dominant } \\
\text { staple }(\%)\end{array}$ & $\begin{array}{l}\text { Population } \\
\text { depending on } \\
\text { sago as dominant } \\
\text { or subdominant } \\
\text { staple }(\%)\end{array}$ & & & \\
\hline & $\begin{array}{l}\text { aPopulation } \\
\text { Est. }\end{array}$ & 'Population Est. & & & \\
\hline Western & 101,853 & 8865 & 141,230 & 72.1 & 78.4 \\
\hline Gulf & 41,828 & - & 65,002 & 64.3 & 64.3 \\
\hline Central & - & - & 148,230 & 0.0 & 0.0 \\
\hline Milne Bay & - & 17,546 & 182,324 & 0.0 & 9.6 \\
\hline Oro & 3310 & - & 88,695 & 3.7 & 3.7 \\
\hline $\begin{array}{l}\text { Southern } \\
\text { Highlands }\end{array}$ & 8355 & 8844 & 415,877 & 2.0 & 4.1 \\
\hline Enga & - & - & 340,480 & 0.0 & 0.0 \\
\hline $\begin{array}{l}\text { Western } \\
\text { Highlands }\end{array}$ & - & - & 364,335 & 0.0 & 0.0 \\
\hline Simbu & 626 & - & 180,575 & 0.3 & 0.3 \\
\hline $\begin{array}{l}\text { Eastern } \\
\text { Highlands }\end{array}$ & - & - & 282,523 & 0.0 & 0.0 \\
\hline Morobe & 2149 & - & 330,550 & 0.7 & 0.7 \\
\hline Madang & 23,418 & 1456 & 250,425 & 9.4 & 10.0 \\
\hline East Sepik & 106,291 & 79,359 & 255,752 & 41.6 & 72.6 \\
\hline Sandaun & 124,312 & 8065 & 157,189 & 79.1 & 84.2 \\
\hline Manus & 22,294 & - & 31,865 & 70.0 & 70.0 \\
\hline $\begin{array}{l}\text { New } \\
\text { Ireland }\end{array}$ & 16,938 & 1604 & 96,361 & 17.6 & 19.3 \\
\hline $\begin{array}{l}\text { East New } \\
\text { Britain }\end{array}$ & - & - & 195,689 & 0.0 & 0.0 \\
\hline $\begin{array}{l}\text { West New } \\
\text { Britain }\end{array}$ & - & - & 160,176 & 0.0 & 0.0 \\
\hline $\begin{array}{l}\text { North } \\
\text { Solomon }\end{array}$ & - & - & 144,978 & 0.0 & 0.0 \\
\hline Total & 451,374 & 125,739 & $3,832,256$ & 11.8 & 15.1 \\
\hline
\end{tabular}

Data Source:

$N B$ : Three additional provinces, namely, the National Capital District, Jiwaka, and Hela have been formed since this information was first published

${ }^{a}$ Bourke and Harwood 2009, Agricultural Systems of Papua New Guinea

${ }^{b}$ National Statistics Office, Port Moresby 
periods over many months so long as it is kept stored in a good condition (Bosro et al. 1999).

\subsubsection{Sago Consumption Patterns in Papua New Guinea}

Sago starch is a very convenient food staple available in the local communities in PNG, prepared and consumed daily at all meals and as a snack in various ways just like rice is in Asian countries. Sago consumption in PNG as shown in Table 9.1 varies by province, but the major consuming provinces are Western Province, East Sepik, Sandaun, and Manus, with $70-80 \%$ of the population consuming sago (Bourke and Harwood 2009). Some provinces are indicated as non-sago consuming, but sago is sold in supermarkets and other distribution channels indicating that consumption of sago exists.

Consumption of sago in PNG is very low and in reality has diminished over the past 50 years from $16 \%$ to $10 \%$ of the total annual food consumption. Declining sago consumption may also be overshadowed by alternative convenient staples like rice that is becoming a major food staple in urban centers (Bourke and Harwood 2009).

The total annual production of sago in PNG is estimated to be around 100,000 mt (Gibson 2001); however, considering the total hectarage of sago to be 1 million, there is scope for a greater amount of sago to be produced. If on average there are 20 sago stands per ha giving a minimal yield of $50 \mathrm{~kg}$ per stand, then a reasonable estimate of $1 \mathrm{mt}$ per ha is possible. This should amount to an estimate of 1 million $\mathrm{mt}$ of sago starch reserve in PNG. The potential for $50 \%$ of this, or $500,000 \mathrm{mt}$, as a conservative estimate to be harvested annually in reality would be a significant contribution to national food security as well as to the global market.

\subsubsection{Sago Cropping Provides Food Security in Papua New Guinea}

Sago is produced and consumed throughout the year and is the most secure food source for communities in rural PNG. Sago starch is obtained mainly from the palm family Arecaceae of only one species Metroxylon sagu, with two main cultivars identified as the spiny and the non-spiny. Sago palms are perennial and nonseasonal with a long maturity stage of 2 years as indicated by the inflorescence protruding from its head after which the palm dies. At this fell ripen stage, sago starch yield is at its maximum (Schuiling 1995).

Although there is some cultivation of selected sago stands by villagers, commercial farming is unheard of in PNG (Power 1999). During food shortages, mature or even immature sago palms are readily harvested and processed. New sago is pro- 
duced when old stocks reach low levels or when stands mature and have to be harvested. Sago making is often a communal activity with the extended family helping and sharing harvested sago using a payback system. This enables sago logs to be shared among a number of households, conserving other sago stands to be processed at a later time when needed (Wamala 1999).

Sago generates much interest in the world as an adaptable climate changeresilient crop, mitigating global warming through carbon $\left(\mathrm{CO}_{2}\right)$ sequestration while surviving in hostile swampy non-arable environments unsuitable for agriculture (Schuiling 1995). Sago palm forest carbon dynamics estimates a carbon sink capacity of $8.3 \mathrm{mt}$ per ha annually as convertible carbohydrate (Inubushi et al. 1998). The East Sepik and Gulf regions of PNG are home to 1 million ha of sago palms, close to $41 \%$ of the global total, behind Indonesia which has $47 \%$ of the total global palms (Flach 1980; Schuiling 1995).

\subsubsection{Potential for Sago Addressing Food Insecurity in Papua New Guinea}

It is imperative that PNG revisits its policy on sago as a potential indigenous food source. PNG's agricultural production growth rate of $1 \%$ lags behind a high population growth rate of $3 \%$ resulting in a deficiency in food supply that is being serviced through importing rice and cereal (Bourke et al. 2001; Bourke and Harwood 2009).

The starch density per hectare compared to other starchy crops is very high and dependent on the cultivar and size of logs but also on the processing method, such as degree of milling and extraction efficiency (Sopade 1999). The amount of starch produced per palm per ha can vary between 3.5 to as high as $6 \mathrm{mt}$ per ha or $65-100 \mathrm{~kg}$ per palm. It has been considered as a potential food source for an increasing world population (Haska 1995). It, however, takes 7-10 years for sago palms to mature before they can be harvested. Sago is propagated mostly by suckers rather than by seed. Sizable clusters per grove may allow for palms to mature at regular intervals of around 42 palms per ha per annum (Tie and Lim 1991).

Palms from germinated seeds normally take longer to mature, 10 years, and are less suitable as a regular food crop. The larger hapaxanthic, non-soboliferous sago species Metroxylon salomonense Becc., or dry land sago, is mostly planted for use as a source of low-cost roof thatching and building material (Paijmans 1980). However, efforts are being made to make use of this wasted opportunity to process the pith into starch. Current work in these areas promotes the palm as an alternate food crop contributing toward food security in high population density areas, where land is scarce as it is in island communities. 


\subsection{Traditional Processing of Sago Starch in Papua New Guinea}

Sago processing in villages by traditional methods is shown in Fig. 9.2 and is similar throughout the country, as it has been for generations. Traditional methods of sago production and storage in PNG have been reviewed elsewhere by Greenhill (2006). Extraction yields of traditionally processed sago are still very poor due to their crudeness (Sopade 1999).

Sago processing can take more than 1 day to complete depending on workload, number of people involved, and location in relation to a water source and the village. The main stages of traditional sago making are shown below. Figure 9.2a-c shows milling of the pith and then washing the milled pith into a trough fixed at a sloping angle to the ground, as shown in Fig. 9.2d. The starchy liquid runs through filters at the top end of the trough into a collecting vat. The suspension is allowed to settle out, and the starch is collected in the vat for a few hours before the clear water is decanted off (Fig. 9.2e). The wet sago starch cake (Fig. 9.2f) is then removed and taken in baskets, bags, or other containers to the village to be stored by various methods, such as by wrapping with leaves and storing in pots, in plastic bags, or under water in containers.

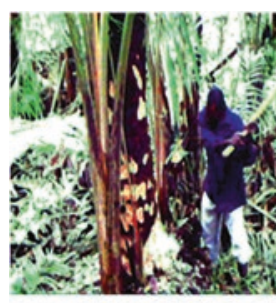

a. Harvesting of selected mature palm

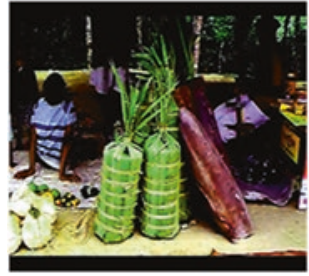

f. Package, storage and end-use

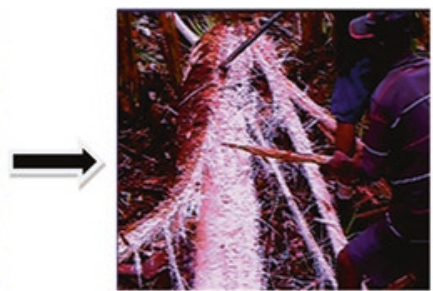

b. Cleaning trunk and debarking of trunk

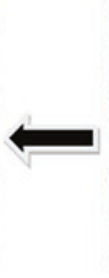$$
\text { e. }
$$

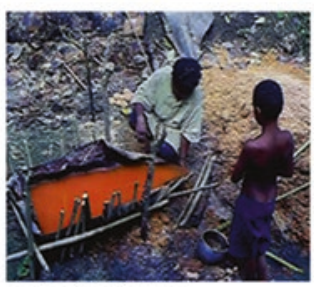

e. Decanting of water and collecting sago starch

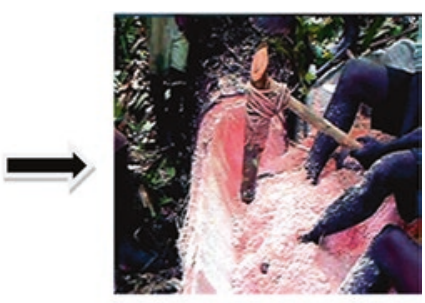

c. Pounding of fibrous pith

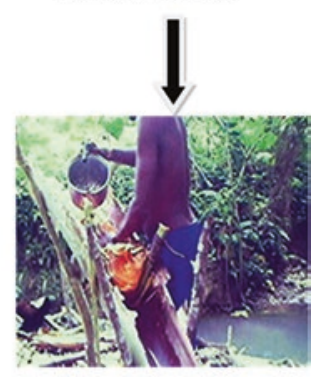

d. Extraction of milled pith

Fig. 9.2 Major stages of traditional processing of sago practiced in Papua New Guinea. (a) harvesting of selected mature palm, (b) cleaning trunk and debarking of trunk, (c) pounding of fibrous pith, (d) extraction of milled pith, (e) decanting of water and collecting sago starch, (f) package, storage and end-use 


\subsubsection{Traditional Methods of Storing Sago}

Sago starch storage practices vary with communities from dry storage of wrapped or covered sago to wet storage with sago suspended in water held in carved wooden canoes, containers, or wrapped and suspended in water holes for extended periods (Greenhill 2006; Pue 2013).

\subsubsection{Dry Storage of Sago}

Sago can be stored for long periods if properly dried, as in some island communities in PNG such as in Manus and New Ireland provinces, or packaged in moistureproof containers as is done for the export market in Malaysia and other Asian countries (Pue 2013).

In the Western Province of PNG, sago is wrapped and placed into large woven rattan cane baskets for storage over extended periods. The moist improperly dried sago stored this way has been found to support the growth and proliferation of fungi (Greenhill et al. 2007a). In a similar practice, fresh sago is usually wrapped in sago, banana, or other leaves and stored for extended periods in the Maprik area of East Sepik Province (Greenhill 2006). There are variations to dry storage, such as the burning of freshly wrapped sago to produce a skin around the sago that is peeled off before the dry sago is properly wrapped and stored.

\subsubsection{Wet Storage of Sago}

The Sepik River people of East Sepik Province, however, do not store sago in a dry form, the way the Maprik and Western Province people do. Sago starch is submerged in water in wooden dugout canoes or containers. The water in the containers is changed regularly to remove the stench and keep the sago fresh. No cases of SHD have been reported in this major sago-producing area, and the water-storage method has been recommended as a safe way to store sago, according to Greenhill (2006), due to its food safety, keeping quality of sago (Greenhill 2006; Pue 2013).

\subsection{Food Safety of Sago in Papua New Guinea}

A food staple can be a vehicle for diseases, in particular, if it is a major staple eaten daily like sago. Its exposure during processing to various sources of contaminants is widely expected. As is typical of subsistence communities which have a less diverse food staple base, accessing other foods during food shortages is a major problem. As a consequence, old sago is sometimes eaten in such dire situations (Bosro et al. 1999; Greenhill 2006). 
The commercialization of sago for domestic consumption or export is impeded by poor food safety quality and health standards (Power 1999). Reduced consumer confidence in food safety means diminished economic returns to producers, with potential cascading effects on the usability of sago as food. Because sago is mostly produced for subsistence purposes, it is not subjected to monitoring under the PNG health and sanitation regulations like other processed foods. The risk to the consuming population from sago exposed to food- and waterborne diseases is too high to ignore and is a major concern to the PNG government. A set of hazard analysis and critical control point (HACCP) protocols, outlined in Fig. 9.4, have been developed from recent sago investigations (Greenhill 2006; Pue 2013).

\subsubsection{Nutrition, Health, and Welfare Status of Sago Communities}

Sago is regarded a poor man's food, lacking in most nutrients and having a low caloric value of $3750 \mathrm{kcal} / \mathrm{kg}$, as it is entirely starch. A diet composed of sago and other foods is always recommended to complement nutrient deficiencies and achieve high caloric values. This is not always possible for most of these communities which depend on wetlands that for long periods are under water (Mueller et al. 2001). Most of these communities are impoverished with little or no alternative food sources and are economically disadvantaged (Mueller et al. 2001). This restricts the diet solely to sago as a daily food source for prolonged periods of days to weeks, with little or no access to mixed diets of game, fish, or other bush foods. The poor nutritional status of these communities may be a prevalent factor contributing to poor general health and vulnerability to diseases (Gibson 2001; Muller et al. 2002).

\subsubsection{Public Health Concerns on Traditional Production and Storage of Sago}

Sago stored for longer than 4 weeks in porous containers, such as those woven from rattan, palm, or other leaves and bark, were mostly found to contain molds. Common filamentous fungi normally associated with mycotoxin production were present in more than $50 \%$ of sago samples analyzed in an investigation by Greenhill et al. (2008).

Foodborne illnesses may be unavoidable for foods produced in an environment that is host to contaminants and their agents. The safety of sago is compromised by the quality imparted by the poor hygienic practices and storage conditions employed. The socioeconomic impact of SHD outbreaks is unknown, but the burden in cost to the public health service is probably less notable than more common diseases in PNG like malaria, HIV-AIDS, and TB, among others (Pue 2013). 


\subsubsection{The Prevalence of Fungi in Sago and Its Implication on Food Safety}

Fungi have long been suspected of having some role in SHD with the etiological agent being a contaminant introduced as metabolic products of fungi onto sago (Taufa 1974; Donovan et al. 1977; Stace et al. n.d.). Sago starch in the pith is known to be sterile but as soon as it is exposed, during processing, becomes contaminated with microorganisms from unsanitary milling implements (Greenhill et al. 2007b, 2010). Investigations by Greenhill (2006) and Pue (2013) have identified two potential contamination points as (i) preharvest infection of the palm (Fig. 9.3a) and (ii) postharvest infection (Fig. 9.3b) during processing, through handling and from utensils such as the palm leaf sheeting on which the sago pith is placed.

\section{Preharvest Infection}

It has been observed that pathologically-infected palms (Fig. 9.3a) can be a source of fungal contamination. Despite removing the large portions of the rotten trunk, infection was seen to have spread throughout the whole palm as evidenced by black spots of fungi in the pith (Pue 2013). Sago produced from infected palms are bound to contain fungi let alone microorganisms that would lead to food spoilage if not food poisoning.

Sometimes there can be delays in the sago pith pounding and washing steps where a trunk is left unattended and exposed over many days. In some of the local communities visited, delayed processing of sago existed so as to extend the food supply. Food security took precedence over food safety through intermittent processing of felled logs done over a number of days (even weeks) by which time some logs would already have fungal growth (Pue 2013). In such cases the visible appear-
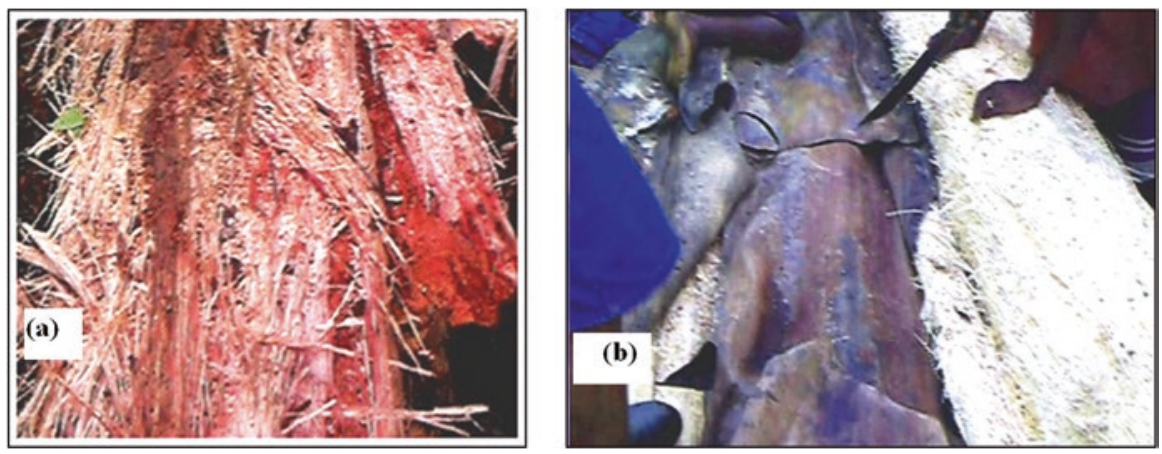

Fig. 9.3 Evidence of preharvest infection of palm and sago making utensils. (a) Reddish rotten base of over matured sago palm, (b) blue moldy spadix sheets showing fungal growth ready to be used to place the milled sago 
ance of the sago pith or milled sago showed inherent biochemical changes from exposure and microbial growth.

\section{Postharvest Infection}

The milled pith of the harvested palm is exposed to contamination from human handling and unsanitized equipment like implements left unwashed from the last sago making, apart from general poor hygiene practices. For example, in Fig. 9.3b, the old palm spadix being placed for the milled pith to be pounded on has bluish mold growth. This spadix may have been used in previous sago making activities (Pue 2013).

Water from natural streams and rivers used in sago processing is also a major contamination source, if it is from an environment that is heavily used by humans, animals, and other users (Greenhill et al. 2010). High levels of microbial contamination, in particular, E.coli, were found in surveys in the waters and sago from around Lae and different parts of PNG (Omoloso and Bomaigi 1996). The risks from waterborne diseases are evident by fecal contamination, and generally high microbial loads in traditionally processed sago are a public health concern for most communities in PNG (Omoloso 1999; Greenhill et al. 2007b).

\subsubsection{Sago Hemolytic Disease in Papua New Guinea}

There are no known reports of SHD occurring in other Southeast Asian-Pacific countries, where sago starch is also produced and consumed. SHD is the acute intravascular hemolysis of red blood cells arising from the consumption of moldy sago. The symptoms of SHD are usually manifested 12-20 h after a meal and commonly include a rapid onset of fever with vomiting, severe diarrhea, jaundice, reddish brown urine, lethargy, and mental confusion. It has been estimated that 2 out of every 10,000 people are affected annually by SHD in PNG. Outbreaks of SHD in PNG are sporadic but are sometimes fatal if severe and untreated, with mortality rates of reported outbreaks estimated as high as 25\% (Greenhill 2006) and a health concern.

\subsubsection{Reported Outbreaks of Sago Hemolytic Disease in Papua New Guinea}

Information on SHD outbreaks in PNG is scarce and not readily available. SHD episodes as marked on the map in Fig. 9.1 show three provinces: East Sepik reporting 2, Madang 1, and the Western Province with 12, the most cases including recent outbreaks. These reports are from case notifications at medical centers over the past 30 years (Greenhill 2006). 
The two initial outbreaks reported at the Maprik hospital, East Sepik Province, in 1973 and 1974, also drew attention to previous outbreaks locally known to medical workers but not documented, suggesting that SHD was underreported (Taufa 1974). There is credible information from local sago-producing communities that sago over 5 weeks old would be unfit for consumption; however, it is eaten during times of food shortage (Donovan et al. 1977; Stace et al. n.d.).

\section{Hemolytic Fungi Isolated from Sago}

Research studies into SHD in the past have all suspected fungi as the causative agent. In 1977, an investigation by Donovan et al. (1977) on two early episodes in the Western Province found various species of bacteria but strongly implicated fungi. In the study by Greenhill (2006), 21 fungal strains isolated from sago and cultivated as pure cultures on wheat tested positive for common mycotoxins. Considerable amounts of citrinin were produced by 14 of the isolates and small amounts of sterigmatocystin (Greenhill et al. 2008). Seven fungal isolates from four genera Penicillium, Aspergillus, Trichoderma, and Fusarium including one from an implicated sago showed varying degrees of hemolytic activity on human erythrocytes as shown in Table 9.2.

\subsection{The Way Forward for a Safer Sago Product in Papua New Guinea}

It is of major economic concern that sago contaminated with SHD reduces the quantity of available low-cost food as well as negatively impacting demand for sago. Sago is now listed under the PNG National Agriculture Quarantine Inspection

Table 9.2 Hemolytic activity of fungi isolated from sago

\begin{tabular}{l|l|l}
\hline Organism & Hemolytic activity (crude extract) & Comments \\
\hline Yeast & & 8 isolates 6 unidentified \\
\hline Geotrichum candidum link & $>50 \%$ over $24 \mathrm{~h}$ & Weak hemolysis \\
\hline Candida tropicalis & $>50 \%$ over $24 \mathrm{~h}$ & Weak hemolysis \\
\hline Fungi & & 7 isolates \\
\hline Aspergillus flavipes & Hemolytic & \\
\hline Fusarium semitectum & $>40 \%$ in $2 \mathrm{~h}$ & $2-100 \%$ hemolysis in $6 \mathrm{~h}$ \\
\hline Penicillium citrinum $(3$ isolates) & Highly hemolytic & \\
\hline Penicillium brevicompactum & $40 \%$ after $8 \mathrm{~h}$ & \\
\hline Trichoderma virens & $>80$ in $30 \mathrm{~min}$ & Control \\
\hline Trichoderma reeisei & $>80$ in $2 \mathrm{~h}$ &
\end{tabular}

Source: Greenhill et al. (2009)

Except for few known hemolytic toxins of fungi like that of Aspergillus fumigatus (Kamaguchi et al. 1979; Yokota et al. 1984), mycotoxins are not known to be hemolytic as confirmed by tests (Greenhill 2006) 


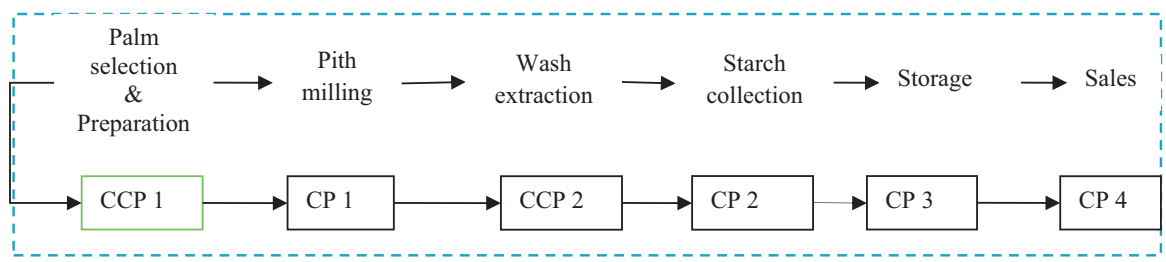

Fig. 9.4 HACCP protocols for safe sago making where $\mathrm{CCP}$ is a critical control point and $\mathrm{CP}$ is a control point

Authority www.NAQIA.gov.pg as requiring testing for food safety. The application of good manufacturing practices (GMP) guided by HACCP protocols (Fig. 9.4) achieved through research findings will pave the way for safer sago products of economic importance becoming available.

Two critical control points identified for careful monitoring in traditional sago making processes are the preharvest stage $\mathrm{CCP} 1$, when selecting the palm, and the postharvest stage $\mathrm{CCP} 2$. It is further recommended that the milling of the pith takes place in the shortest time possible to prevent microbial growth. The use of clean implements and clean water to extract the sago is highly important in producing a safe food.

In conclusion, sago is an underutilized indigenous crop that is well adapted to PNG conditions, having great potential in addressing the food insecurity status of the country. Food security through sago in PNG would be pursued on two fronts as discussed in this chapter through:

1. Commercial cropping of suitably selected cultivars

2. Regulated processing guided by good manufacturing practices addressing food safety issues using the recommended HACCP procedures

\section{References}

Abd-Aziz S (2002) Sago starch and its utilisation. J Biosci Bioeng 94:526-529

Boonsermsuk S, Jong F, Anai T et al (1999) Classification of sago palm (Metroxylon sagu Rottb.) cultivars by randomly amplified polymorphic DNA analyses. SABRAO J Breed Genet $31: 109-117$

Bosro J, Sau M, Kasindu P (1999) Sago and food security: community concerns, questions and suggestions. In: Sopade P (ed) Sago starch and food security in PNG: first national sago conference. Unitech Press, Lae, pp 70-75

Bourke RM, Harwood T (eds) (2009) Food and agriculture in Papua New Guinea. ANU, Canberra

Bourke RM, Allen MG, Salisbury JG (2001) An overview of food security. In: Bourke RM, Allen MG, Salisbury JG (eds) Food security for Papua New Guinea. Proceedings of the Papua New Guinea food and nutrition 2000 conference, PNG University of Technology, Lae, PNG, 26-30 June 2000. Australian Centre for International Agricultural Research (ACIAR), Canberra, pp 5-14

Donovan KO, Shaw DE, Amato D (1977) Sago hemolysis - clinical features and microbiological studies. Papua New Guinea Med J 20:167-174 
Flach M (1980) Sago palms from equatorial swamps; a competitive source of tropical starch. In: Stanton WR, Flach M (eds) Sago: the equatorial swamp as a natural resource, proceedings of the second international sago symposium Kuala Lumpur. Martinus Nijhoff Publishers, The Hague, pp 110-127

Gemo O (1999) Sago for thought. In: Sopade PA (ed) First national sago conference- sago starch and food security in Papua New Guinea. Unitech Press, Lae, pp 121-125

Gibson J (2001) The nutritional status of PNG's population. In: Bourke RM, Allen MG, Salisbury JG (eds) Food security for Papua New Guinea, Food security for Papua New Guinea. Proceedings of the Papua New Guinea food and nutrition 2000 conference, PNG University of Technology, Lae, PNG, 26-30 June 2000. Australian Centre for International Agricultural Research (ACIAR), Canberra, pp 407-413

Greenhill A (2006) Food safety and security of sago starch in Papua New Guinea. PhD, James Cook University

Greenhill AR, Shipton WA, Blaney BJ, Warner JM (2007a) Fungal colonization of sago starch in Papua New Guinea. Int J Food Microbiol 119:284-290

Greenhill AR, Shipton WA, Omoloso AD et al (2007b) Bacterial contamination of sago starch in Papua New Guinea. J Food Prot 70:2868-2872

Greenhill AR, Blaney BJ, Shipton WA et al (2008) Mycotoxins and toxigenic fungi in sago starch from Papua New Guinea. Lett Appl Microb 47:342-347

Greenhill AR, Shipton WA, Blaney BJ et al (2010) Spontaneous fermentation of traditional sago starch in Papua New Guinea. Food Microbiol 26:136-141

Haska N (1995) Study of productivity and starch yield of sago palm in West Java. Acta Hort 389:217-222

Inubushi K, Hadi A, Okazaki M, Yonebayashi K (1998) Effect of converting wetland forest into sago palms on methane gas flux and organic carbon dynamics in tropical peat soil. Hydrol Process 12:2073-2080

Kamaguchi A, Yokota K, Sakaguchi O (1979) Investigation of the hemolytic site of asp-hemolysin. Japan J Med Sci Biol 32:118-121

Kjari A, Barfod AS, Asmussen CB, Seberg O (2004) Investigation of genetic and morphological variation in the sago palm (Metroxylon sagu; Arecaceae) in Papua New Guinea. Ann Bot (London) 94:109-117

McClatchey W, Manner HI, Elevitch CR (2004) Metroxylon amicarum, M. paulcoxii, M. sagu, M. salmonense, M. vitiense, and M. warburgii (sago palm). Permanent Agricultural Resources, Honolulu

McClatchey W, Manner HI, Craig RE (2006) Metroxylon amicarum, M. paulcoxii, M. sagu, M. salomonense, M. vitiense, and M. warburgii (sago palm) Arecaceae (palm family). Species Profiles for Pacific Island Agroforestry www.traditionaltree.org

Morauta L (1982) Sago for food in a changing economy. PNG Institute of Applied Social and Economic Research, Discussion Paper 44:39-76

Mueller I, Vounatsou P, Smith T, Allen B (2001) Subsistence agriculture and child growth in Papua New Guinea. Ecol Food Nutr 40:367-395

Muller I, Betuela I, Hide R (2002) Regional patterns of birthweights in Papua New Guinea in relation to diet, environment and socio-economic factors. Ann Hum Biol 29:74-88

Omoloso AD (1999) Microbial profile of sago starch from different area of Papua New Guinea. In: Sopade P (ed) Proceedings of the first national sago conference. Unitech Press, Lae, pp 85-90

Omoloso AD, Bomaigi A (1996) Microbiological suitability of drinking water from settlements in and around Lae. Proceedings of the 9th annual congress of PNG Institute of Chemistry. PNG University of Technology, Lae, pp 82-87

Paijmans K (1980) Ecological notes on sago in New Guinea. In: Stanton WR, Flach M (eds) Sago. The equatorial swamp as a natural resource. Proceedings of the second international sago symposium. Martinus Nijhoff Pub, The Hague, pp 9-12

Power AP (1999) The sago industry for Papua New Guinea: the time is now. In: Sopade PA (ed) Sago starch and food security in Papua New Guinea. The proceedings of the first national sago conference 15-16 November, vol 1999. Unitech Press, Lae, pp 1-13 
Pue AG (2013) Studies on haemolytic compounds from fungi of sago and their role in sago haemolytic disease in Papua New Guinea. PhD, University of Queensland

Schuiling DL (1995) The variability of the sago palm and the need and possibilities for its conservation. Acta Hort 389:41-62

Sopade PA (1999) Sago starch in Papua New Guinea: making the most of it. In: Sopade PA (ed) First national sago conference. Unitech Press, Lae, pp 22-25

Stace J, Pitt JL, Conway PL, Adams RF (n.d.) Sago haemolysis, a mycotoxicosis in Papua New Guinea, unpublished

Taufa T (1974) Sago haemolytic disease. Papua New Guinea Med J 17:227-228

Temu P (2006) Food security in PNG. Post Courier, Port Moresby 23 Oct 2006

Temu PI, Saweri W (2001) Nutrition in transition. In: Bourke RM, Allen MG, Salisbury JG (eds) Food security for Papua New Guinea. Proceedings of the Papua New Guinea food and nutrition 2000 conference. PNG University of Technology, Lae, PNG, 26-30 June 2000. Australian Centre for International Agricultural Research (ACIAR), Canberra, pp 395-406

Tie Y-L, Lim E-TK (1991) The current status and future prospects of harvestable sago palms in Sarawak. In: Ng TT, Tie YL, Kueh HS (eds) Towards greater advancement of the sago industry in the '90s: proceedings of the fourth international sago symposium. Kuching, Sarawak, pp 11-16

Wamala M (1999) Distribution of sago as staple food in southern region (Western, Gulf, Central, Milne Bay, and Oro Provinces). In: Sopade P (ed) Sago starch and food security in PNG: first national sago conference. Unitech Press, Lae, pp 56-69

Wang WJ, Powell AD, Oates CG (1996) Sago starch as a biomass source: raw sago starch hydrolysis by commercial enzymes. Bioresour Technol 55:55-61

Yokota K, Kamaguchi A, Sakaguchi O (1984) Studies on the toxin of Aspergillus fumigatus. XVIII. Photooxidation of Asp-hemolysin in the presence of various dyes and its relation to the site of hemolytic activity. Microbiol Immunol 28:385-391

Open Access This chapter is licensed under the terms of the Creative Commons Attribution 4.0 International License (http://creativecommons.org/licenses/by/4.0/), which permits use, sharing, adaptation, distribution and reproduction in any medium or format, as long as you give appropriate credit to the original author(s) and the source, provide a link to the Creative Commons license and indicate if changes were made.

The images or other third party material in this chapter are included in the chapter's Creative Commons license, unless indicated otherwise in a credit line to the material. If material is not included in the chapter's Creative Commons license and your intended use is not permitted by statutory regulation or exceeds the permitted use, you will need to obtain permission directly from the copyright holder. 